Jurnal ECOTIPE, Volume 7, No. 1, April 2020, Hal. 47-54

p-ISSN 2355-5068, e-ISSN 2622-4852

Akreditasi Kemenristekdikti (SINTA 4), SK. No.10/E/KPT/2019

DOI: 10.33019/ecotipe.v7i1.1467

\title{
Pemanfaatan MATLAB Untuk Penentuan Jalur Terpendek Evakuasi Bencana Tsunami di Wilayah Kecamatan Cilacap Selatan
}

\author{
Sugeng Dwi Riyanto ${ }^{1}$, Artdhita Fajar Pratiwi ${ }^{2}$, Rostika Listyaningrum ${ }^{3}$ \\ ${ }_{1,2,3}$ Program Studi Teknik Elektronika Politeknik Negeri Cilacap \\ sugengdr82@gmail.com,art_dhita@yahoo.com,li_sa007@pnc.ac.id
}

\begin{abstract}
The South Cilacap district is one of the area in Cilacap regency with the highest population density and the most prone area of tsunami disaster. Unfortunately, most of the main roads in South Cilacap district is parallel to the coastline. This condition will slow down the evacuation of residents to safe locations. In 2006 and 2017, Cilacap regency has experienced several earthquake that have a potential of a tsunami. It caused people to panic and tended to choose the evacuation route through the main roads without considering the route became congested and resulted in total congestion. Based on these conditions, a system that contains information about the shortest evacuation route that should be taken by the residents to a safe location is needed. The shortest evacuation route is determined using MATLAB software. The simulations was creating on MATLAB, there is a starting vertexes as a starting location or location of a tsunami prone area and a finish vertexes as a destination location or a safe location from a tsunami disaster. By using MATLAB software, it can simulate the shortest path for tsunami evacuation in the South Cilacap district area along with the distance and graphic images.
\end{abstract}

Keywords: Shortest Evacuation Path, MATLAB, Finish Vertexs, Starting Vertexs

\section{INTISARI}

Wilayah kecamatan Cilacap Selatan adalah salah satu wilayah di kabupaten Cilacap yang memiliki kerapatan penduduk tertinggi dan merupakan area dengan potensi tsunami terbesar. Akan tetapi, sebagian besar jalan utama di Kecamatan Cilacap Selatan sejajar dengan garis pantai. Kondisi ini akan memperlambat evakuasi penduduk ke lokasi yang aman. Pada tahun 2006 dan 2017, kabupaten Cilacap pernah mengalami beberapa kejadian gempa bumi yang berpotensi tsunami. Hal ini menyebabkan masyarakat menjadi panik dan cenderung memilih jalur evakuasi melalui jalan-jalan utama tanpa mempertimbangkan jalur tersebut menjadi padat dan berakibat menjadi kemacetan total. Berdasarkan kondisi tersebut, diperlukan sebuah sistem yang berisi informasi tentang jalur evakuasi terpendek yang dapat ditempuh oleh masyarakat menuju lokasi aman. Penentuan jalur evakuasi terpendek dilakukan dengan menggunakan perangkat lunak MATLAB. Simulasi yang dibuat pada MATLAB, terdapat titik awal sebagai lokasi awal atau lokasi bahaya tsunami dan titik akhir sebagai lokasi tujuan atau lokasi aman dari bahaya tsunami. Dengam memanfaatkan perangkat lunak MATLAB dapat mensimulasikan jalur terpendek evakuasi tsunami di wilayah kecamatan Cilacap Selatan beserta jarak dan gambar grafiknya.

Kata kunci: Jalur Evakuasi Terpendek, MATLAB, Titik Awal, Titik Akhir

\section{PENDAHULUAN}

Peringatan dini adalah bagian dari pengurangan risiko bencana yang tidak hanya mengenai peringatan yang akurat secara teknis, tetapi juga harus membangun pemahaman risiko yang baik dari suatu peringatan, menjalin hubungan antara penyedia dengan pengguna peringatan, dan juga meningkatkan kemampuan otoritas dan masyarakat untuk bereaksi secara benar terhadap peringatan dini. Prioritas utama evakuasi adalah masyarakat yang tinggal di kawasan beresiko [1]. Oleh karena itu kesiapsiagaan masyarakat di kawasan beresiko perlu ditingkatkan dalam rangka meningkatkan pemahaman jalur evakuasi, lokasi evakuasi dan bangunan evakuasi.

Kabupaten Cilacap memiliki potensi tsunami 
Jurnal ECOTIPE, Volume 7, No. 1, April 2020, Hal. 47-54

p-ISSN 2355-5068, e-ISSN 2622-4852

Akreditasi Kemenristekdikti (SINTA 4), SK. No.10/E/KPT/2019

DOI: 10.33019/ecotipe.v7i1.1467

terbesar di Provinsi Jawa Tengah dan peringkat ketiga dalam skala nasional [2]. Adapun wilayah Kabupaten Cilacap yang berpotensi tsunami dapat dilihat pada Gambar 1.

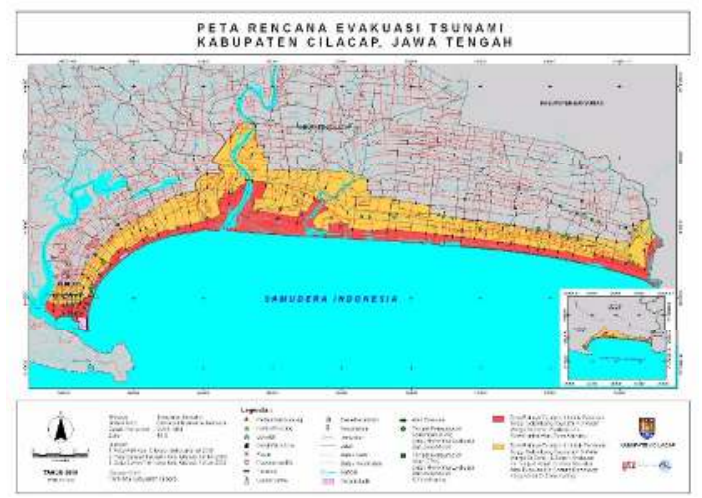

Gambar 1. Zona Potensi Tsunami Kabupaten Cilacap (Sumber: www.gitews.org)

Wilayah Kabupaten Cilacap dengan kerapatan penduduk yang berpotensi tsunami terbesar adalah wilayah Kecamatan Cilacap Selatan. Kecamatan Cilacap Selatan memiliki arah jalur transportasi darat utama yang sejajar dengan garis pantai. Kondisi ini tentunya akan memperlambat evakuasi penduduk ke lokasi yang aman. Beberapa kejadian gempa bumi yang berpotensi tsunami yang dirasakan sampai ke wilayah Kabupaten Cilacap pada tahun 2006 dan 2017 menyebabkan masyarakat menjadi panik dan cenderung memilih jalur evakuasi melalui jalan-jalan utama tanpa memperhitungkan jalur tersebut menjadi padat dan berakibat menjadi kemacetan total. Gambar 2 menunjukkan jalan utama Kecamatan Cilacap Selatan dan sekitarnya.

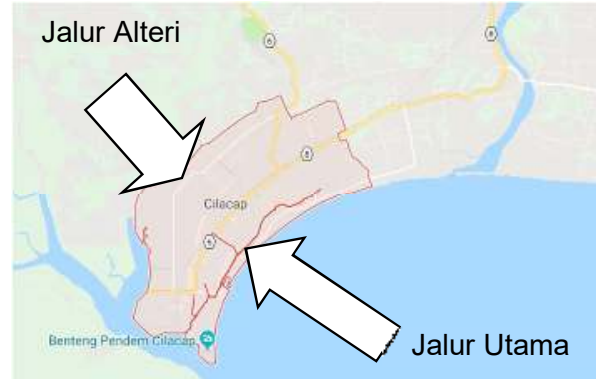

Gambar 2. Jalur Utama Kecamatan Cilacap Selatan dan Sekitarnya (Sumber : Google Maps)
Model evakuasi horizontal untuk Kecamatan Cilacap Selatan tidak dapat dihindari mengingat bangunan evakuasi vertikal sangat terbatas, tidak aksesibel dan tidak sebanding dengan masyarakat yang dievakuasi [3]. Oleh sebab itu, diperlukan analisa perhitungan untuk menentukan jalur terpendek dengan beberapa pilihan algoritma seperti algoritma Djikstra [4], Ant Colony [6], algoritma Bellman-Ford, algoritma FloydWarshall [7], algortima Boids dan Pathfinding [8] dan algoritma A-Star [9]. Selain itu, perlu juga dibuat sistem simulasi [10], untuk mempermudah penyampaian informasi jalur terpendek untuk evakuasi tsunami sampai ke titik aman.

Penelitian ini menghasilkan sistem simulasi menentukan jalur terpendek untuk evakuasi tsunami di wilayah cilacap selatan dengan menggunakan MATLAB. Disamping itu, sistem ini diharapkan dapat menjadi panduan bagi masyarakat agar tidak terjebak dalam kemacetan lalu lintas ketika terjadi kepanikan.

\section{TINJAUAN PUSTAKA}

Gagasan utama dari permasalahan jalur terpendek merupakan suatu jaringan untuk mengarahkan jalan dengan jalur yang terpendek antara dua kota atau dua titik dengan menggunakan beberapa jalur alternatif yang tersedia. Metode ini menggunakan representasi graph untuk memodelkan persoalan yang diwakili sehingga lebih memudahkan penyelesaiannya. Masalahnya adalah bagaimana cara mengunjungi vertek pada graph dari vertek awal ke vertek akhir dengan bobot minimum, dimana dalam hal ini bobot yang digunakan adalah jarak dan kota-kota yang dikunjungi diasumsikan sebagai graph yang saling terhubung (connected graph) antar suatu kota dengan kota yang lainnya. Suatu graph $\mathrm{G}$ disebut terhubung jika untuk setiap vertek dari graph terdapat jalur yang menghubungkan kedua verteks tersebut, atau dengan kata lain graph terhubung jika setiap dua vertek yaitu vi dan vj dalam suatu graph terdapat sedikitnya sebuah edge. Edge pada graph 
Jurnal ECOTIPE, Volume 7, No. 1, April 2020, Hal. 47-54

p-ISSN 2355-5068, e-ISSN 2622-4852

Akreditasi Kemenristekdikti (SINTA 4), SK. No.10/E/KPT/2019

DOI: 10.33019/ecotipe.v7i1.1467

berarah disebut arc [5]. Sebagai ilustrasi dapat dilihat pada Gambar 3. Terdapat sebuah graph berarah yang terdiri dari 6 simpul dan masingmasing lintasan sudah memiliki bobot nilainya tersendiri. Dimisalkan akan ditentukan lintasan terpendek dari simpul 1 menuju simpul lainnya.

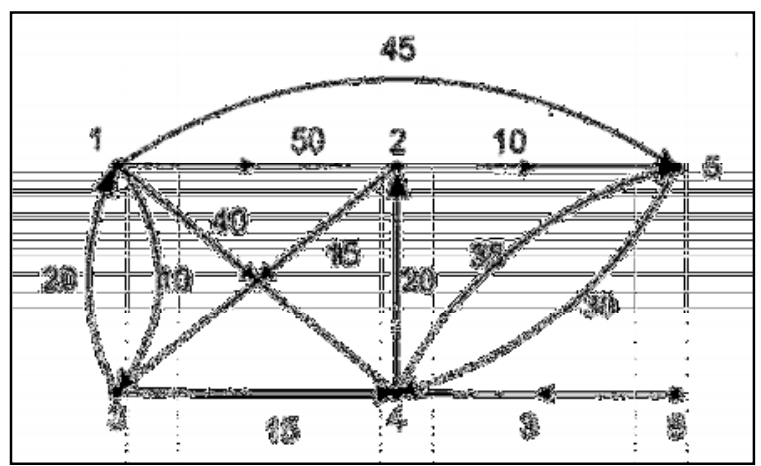

Gambar 3. Contoh Graph untuk Menentukan Lintasan Terpendek

Pada Tabel 1 berikut ini tunjukkan lintasan terpendek dari simpul 1 yang diurutkan dari lintasan terpendek pertama, kedua, ketiga dan seterusnya.

Tabel 1. Lintasan Terpendek dari Simpul 1

\begin{tabular}{|c|c|c|c|}
\hline $\begin{array}{c}\text { Simpul } \\
\text { Asal }\end{array}$ & $\begin{array}{c}\text { Simpul } \\
\text { Tujuan }\end{array}$ & $\begin{array}{c}\text { Lintasan } \\
\text { Terpendek }\end{array}$ & Jarak \\
\hline 1 & 3 & 1,3 & 10 \\
\hline 1 & 4 & $1,3,4$ & 25 \\
\hline 1 & 2 & $1,3,4,2$ & 45 \\
\hline 1 & 5 & 1,5 & 45 \\
\hline 1 & 6 & Tidak ada & - \\
\hline
\end{tabular}

\section{METODE PENELITIAN}

Metode penelitian yang digunakan adalah penelitian kuantitatif. Pada penelitian ini, analisa dan kesimpulan ditarik dari hasil perhitungan dengan menggunakan simulasi penentuan jalur terpendek dengan MATLAB dan diperlukan beberapa tahapan penelitian diantaranya adalah seperti yang ditunjukkan melalui diagram alir pada Gambar 4.

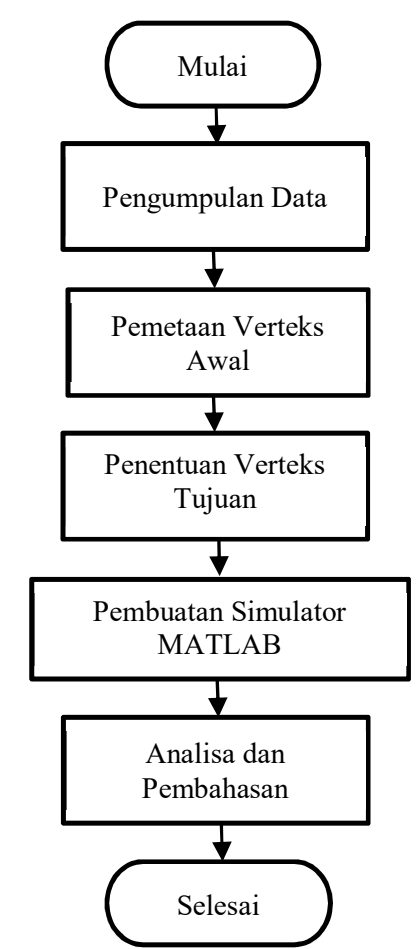

Gambar 4. Tahapan Penelitian

\section{A. Penentuan Verteks (Titik) Awal dan Verteks(Titik) Akhir}

Kegiatan penelitian dimulai dengan melakukan pengumpulan data yakni titik-titik yang berpotensi rawan tsunami yang selanjutnya disebut sebagai Verteks Awal. Data yang diperlukan adalah:

1. Lokasi geografis,

2. Jumlah penduduk,

3. Akses jalan/jalur transportasi

- Panjang jalan

- Lebar jalan

4. Bangunan evakuasi

Data-data tersebut didapatkan dari beberapa cara yaitu :

1. Observasi lapangan,

2. Wawancara dengan berbagai narasumber dari Badan Penanggulangan Bencana Daerah (BPBD), Kelurahan-kelurahan, dan masyarakat secara terstruktur,

3. Studi literatur,

4. Akuisisi data. 
Jurnal ECOTIPE, Volume 7, No. 1, April 2020, Hal. 47-54

p-ISSN 2355-5068, e-ISSN 2622-4852

Akreditasi Kemenristekdikti (SINTA 4), SK. No.10/E/KPT/2019

DOI: 10.33019/ecotipe.v7i1.1467

Parameter-parameter tersebut kemudian diberi nilai untuk menentukan bobot tiap verteks-verteks awal. Kemudian ditentukan verteks-verteks tujuan dan jumlah verteks tujuan yang merupakan lokasi aman, sehingga didapatkan peta evakuasi yang dikelompokan berdasarkan lokasi geografis.

\section{B. Pembuatan Simulasi dengan Perangkat Lunak MATLAB}

Tahapan selanjutnya adalah dengan membuat program dengan menggunakan perangkat lunak MATLAB untuk menghitung dan mensimulasikan jalur terpendek dengan memasukkan parameter-parameter satu persatu untuk tiap-tiap peta yang telah dibuat. Diagram alir dapat dilihat pada pada Gambar 5.

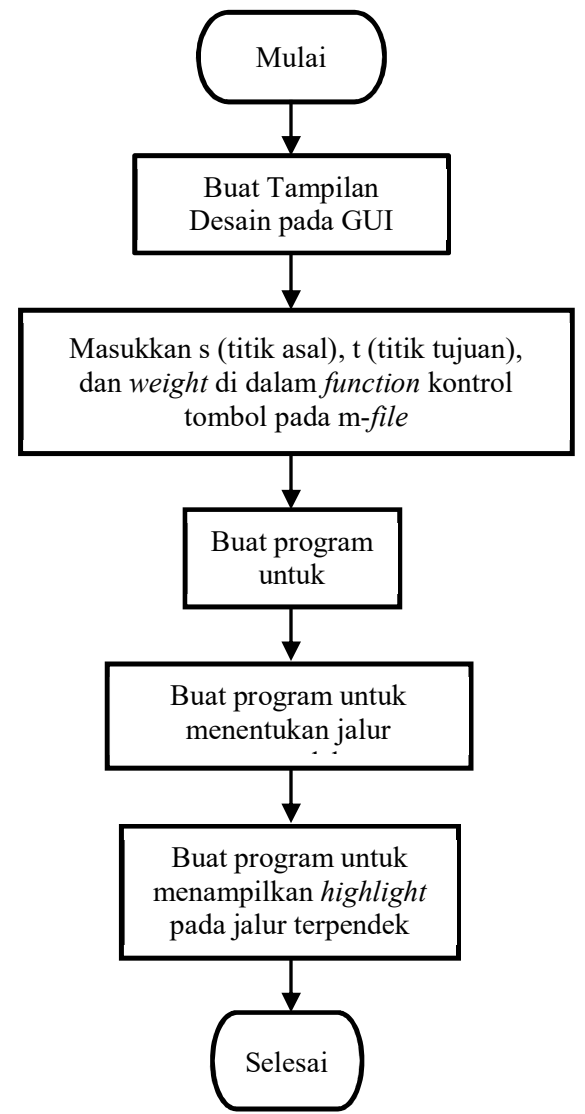

Gambar 5. Diagram alir pencarian jalur terpendek pada Perangkat Lunak MATLAB
Tahap ke-1, diawalai dengan pembuatan desain tampilan pada GUI MATLAB seperti pada Gambar 6.

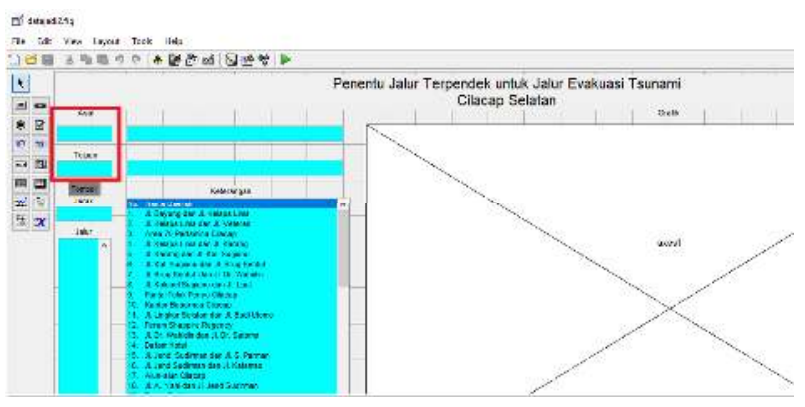

Gambar 6. Tampilan GUI Perangkat Lunak MATLAB

Tahap ke-2, yaitu memasukkan nomor pada teks asal dan teks tujuan sebagai nomor asal daerah dan nomor tujuan daerah evakuasi, dengan cara menuliskan program pada $\mathrm{m}$-file seperti pada Gambar 7.

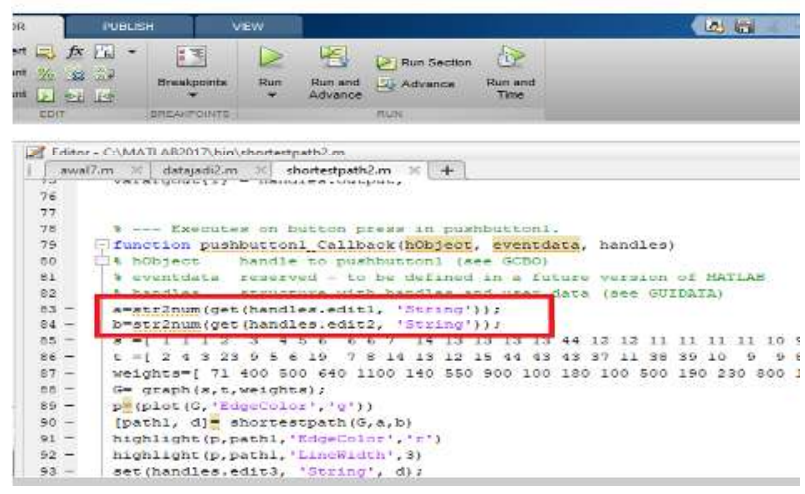

Gambar 7. Tampilan program nomor asal dan tujuan pada $m$-file

Pada Gambar 7 tertulis program pada $\mathrm{m}-$ file : a=str2num (get ( handles.edit1,

'String') );

b=str2num (get (handles.edit2,

'String')) ;

dimana:

- $\mathrm{a}=$ variabel untuk Label asal.

- $\quad b=$ variabel untuk Label Tujuan

- str2num = data string diubah ke data number

- get(handles.edit1) = data number di tempatkan pada alamat Label Asal (edit1) 
Jurnal ECOTIPE, Volume 7, No. 1, April 2020, Hal. 47-54

p-ISSN 2355-5068, e-ISSN 2622-4852

Akreditasi Kemenristekdikti (SINTA 4), SK. No.10/E/KPT/2019

DOI: 10.33019/ecotipe.v7i1.1467

- get(handles.edit2) = data number di tempatkan pada alamat Label Tujuan (edit2)

Langkah ke-3, masukkan data nomor asal dan tujuan beserta jarak masing-masing antara 2 titik (asal dan tujuan) sesuai dengan data atau perhitungan manual yang telah dibuat. Data ini diketikkan secara manual pada MATLAB dikarenakan pada pembacaan data excel tidak bisa menyangkup atau membaca keseluruhan data sehingga menimbulkan data yang rumpang atau hilang, seperti pada Gambar 8.

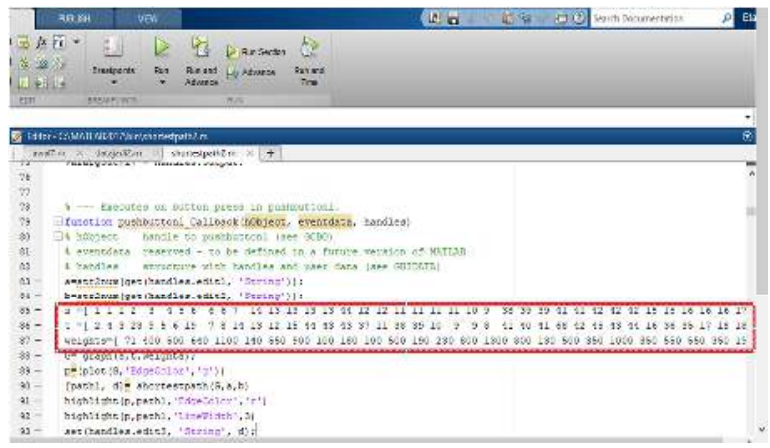

Gambar 8. Penulisan data nomor asal, tujuan dan jarak pada m-file

Pada Gambar 8 tertulis program pada m-file, (misalnya) :

$S=\left[\begin{array}{lllllll}1 & 1 & 1 & 2 & 3 & 4 & 5\end{array}\right] ;$

$t=\left[\begin{array}{lllllll}2 & 4 & 3 & 3 & 9 & 5 & 6\end{array}\right] ;$

weights $=\left[\begin{array}{lllllll}71 & 400 & 500 & 640 & 1100 & 140\end{array}\right.$ 550];

dimana:

- $\mathrm{s}=$ variabel untuk nomor asal

- $\mathrm{t}=$ variabel untuk nomor tujuan

- $\mathrm{w}=$ variabel untuk jarak antar 2 titik (satuan meter)

- Jadi cara membacanya adalah nomor asal $1 \mathrm{ke}$ nomor tujuan 2 memiliki jarak 71 meter, dan seterusnya. Nilai s dan t berjumlah 100 karena ketika data $\mathrm{s}$ dan $\mathrm{t}$ berjumlah lebih dari 100 maka nama titik $s$ dan $t$ tidak dapat ditampilkan pada grafik
Langkah ke-4 yaitu menampilkan hasil jalur terpendek yang akan dilewati untuk arah evakuasi gempa dan menampilkan grafikknya serta highlight. Diketikkan program pada $\mathrm{m}$-file seperti pada Gambar 9.

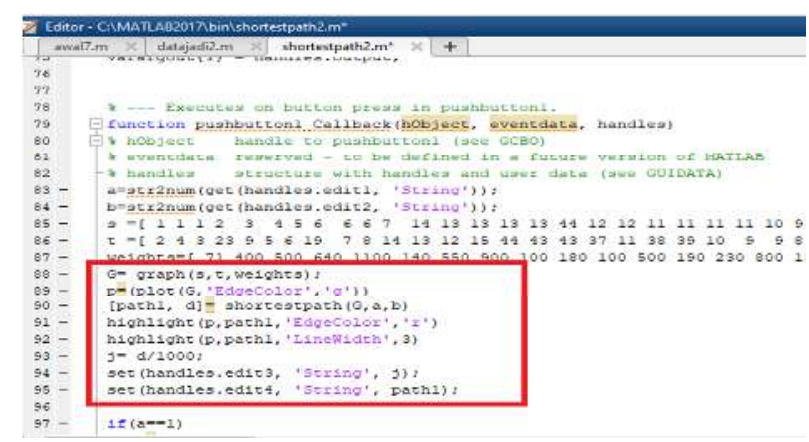

Gambar 9. program nenampilkan grafik dan highlight pada m-file

Pada Gambar 3.6 tertulis program pada mfile:

$\mathrm{G}=\operatorname{graph}(\mathrm{s}, \mathrm{t}$, weights) ;

$\mathrm{p}=(\operatorname{plot}(\mathrm{G}$, 'EdgeColor', 'g') $)$

[path1, d] = shortestpath $(G, a, b)$

highlight (p,path1, 'EdgeColor', 'r')

highlight (p,path1, 'Linewidth', 3)

$j=d / 1000$;

set (handles.edit3, 'String', j);

set (handles.edit4, 'String', path1);

dimana:

- $\mathrm{G}=$ variabel untuk grafik

- graph = fungsi untuk menampilkan grafik.

- (s, t, weights) = data yang ditampilkan pada grafik yaitu nomor asal, nomor tujuan dan jarak antara 2 titik tersebut.

- $p=$ variabel untuk tampilan plot

- plot = fungsi untuk menampilkan plot.

- $(\mathrm{G}$, 'EdgeColor','g') = plot tersebut menampilkan grafik dengan garis penghubung antara titik satu dengan yang lainnya berwarna hijau.

- Path1 = variabel untuk jalur terpendek yang telah ditentukan.

- $\mathrm{d}=$ panjangnya jarak pada jalur terpendek yang telah ditentukan.

- Shortestpath $(\mathrm{G}, \mathrm{a}, \mathrm{b})=$ fungsi untuk menentukan jalur terpendek antara data 
Jurnal ECOTIPE, Volume 7, No. 1, April 2020, Hal. 47-54

p-ISSN 2355-5068, e-ISSN 2622-4852

Akreditasi Kemenristekdikti (SINTA 4), SK. No.10/E/KPT/2019

DOI: 10.33019/ecotipe.v7i1.1467

masukan asal dan tujuan yang diinginkan pada grafik.

- Highlight(p,path1,'EdgeColor','r') $=$ pemberian garis pembeda pada jalur terpendek yang telah ditentukan dengan garis penghubung berwarna merah.

- Highlight(p,path1,'LineWidth','3') = pemberian garis pembeda pada jalur terpendek yang telah ditentukan dengan lebar garis penghubung 3 kali lebih besar dari garis normal.

- $\mathrm{J}=\mathrm{d} / 100 ;=\mathrm{j}$ adalah variabel untuk jarak, jarak yang ditampilkan berada pada satuan $(\mathrm{km})$ karena d (*distance antara 2 titik telah dibagi 1000).

- Set(handles.edit3, 'string', j) = data jarak $(\mathrm{km})$ ditampilkan pada edit teks "Jarak" dengan keterangan nama tag edit3.

- Set(handles.edit4, 'string', path1) = data jalur terpendek ditampilkan pada edit teks "jalur" dengan keterangan nama tag edit4.

Langkah ke-5 menampilkan keterangan nama daerah asal dan tujuan ketika fungsi Tombol Cari ditekan, maka perlu di tuliskan program pada mfile seperti Gambar 10 di bawah ini.

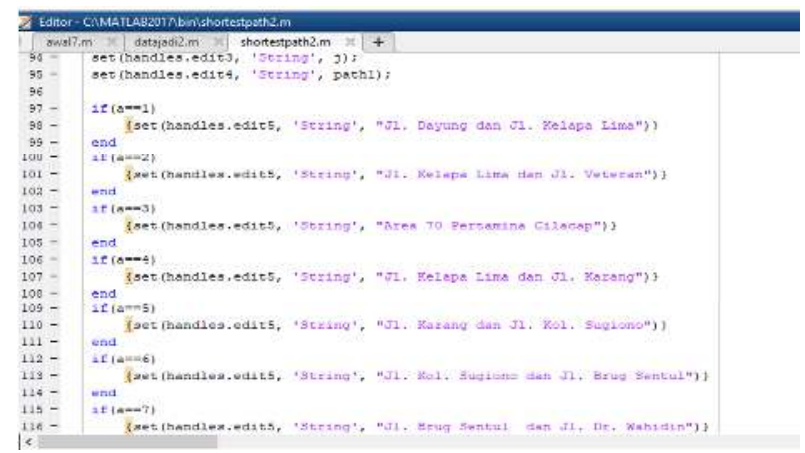

Gambar 10. Program menampilkan nama daerah asal dan tujuan pada $m$-file

Pada Gambar 10 tertulis program pada mfile, (misalnya):

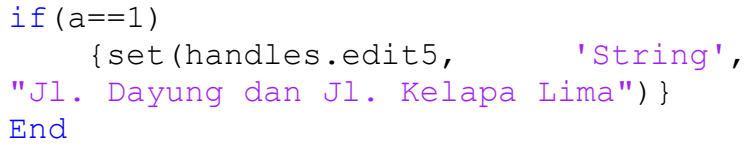

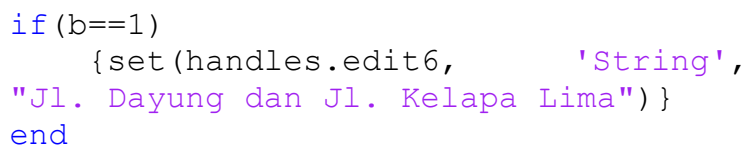

dimana:

- Jika edit teks "asal" diisi dengan angka 1 maka pada teks disebelahnya akan tampil keterangan nama daerah asal nomor 1 yaitu Jl. Dayung dan Jl. Kelapa Lima.

- Jika edit teks "tujuan" diisi dengan angka 1 maka pada teks disebelahnya akan tampil keterangan nama daerah tujuan nomor 1 yaitu Jl. Dayung dan Jl. Kelapa Lima.

\section{HASIL PENELITIAN DAN PEMBAHASAN}

Berdasarkan data yang ada dan hasil wawancara dengan pihak terkait, di Kabupaten Cilacap khususnya bagian Cilacap Selatan diperoleh verteks awal dan verteks akhir sebagai pemetaan.Verteks yang dipetakan sebagai verteks awal (titik awal evakuasi) dibagi menjadi 8 titik di sepanjang garis pantai yaitu Area 70 Pertamina Cilacap, Pantai Teluk Penyu, Perumahan Putri Tegal Kamulyan, Rusunawa, Perumahan Tegal Asri, Rumah Sakit Pertamina Cilacap, Perumahan Shappire Regency, dan Perumahan Taman Gading. Sedangkan verteks tujuan (titik lokasi aman) ditentukan dengan 2 titik yaitu Lapangan Terbang Tunggul Wulung dan Lapangan Jangrana Lebeng atau Lapangan Desa Dondong.

Selain data verteks awal dan verteks akhir, terdapat titik persimpangan atau lokasi-lokasi yang dilintasi oleh jalur yang digunakan dari titik awal ke titik akhir. Total keseluruhan titik persimpangan beserta titik tujuan berjumlah 100 titik.

Setelah menetapkan titik persimpangan, langkah selanjutnya adalah melakukan pengukuran jarak antara titik satu terhadap titik lainnya. Pengukuran ini dilakukan dengan menggunakan speedometer sepeda motor untuk mengukur jarak tempuh dan walking measure untuk mengukur lebar jalan. 
Jurnal ECOTIPE, Volume 7, No. 1, April 2020, Hal. 47-54

p-ISSN 2355-5068, e-ISSN 2622-4852

Akreditasi Kemenristekdikti (SINTA 4), SK. No.10/E/KPT/2019

DOI: 10.33019/ecotipe.v7i1.1467

Kemudian data tersebut diolah menggunakan perangkat lunak MATLAB. Pembuatan desain untuk tampilan simulasi dilakukan pada GUI (Graphical User Interface) MATLAB. Setelah itu, program akan ter-generate secara otomatis ke dalam program $\mathrm{m}$-file pada MATLAB. File $\mathrm{m}$-file inilah yang berfungsi sebagai tempat pembuatan program untuk penetuan jalur terpendek evakuasi tsunami. Langkah awal pembuatan program simulasi ini adalah dengan memasukkan data 100 titik yang telah ditentukan beserta jaraknya.

Pembuatan simulasi ini dapat ditampilkan pada layar figure MATLAB. Untuk menjalankan simulasi ini terdapat 2 data masukan yaitu memasukkan data titik awal dan data titik tujuan (lokasi aman). Tampilan simulasi MATLAB dapat ditunjukkan pada Gambar 11.

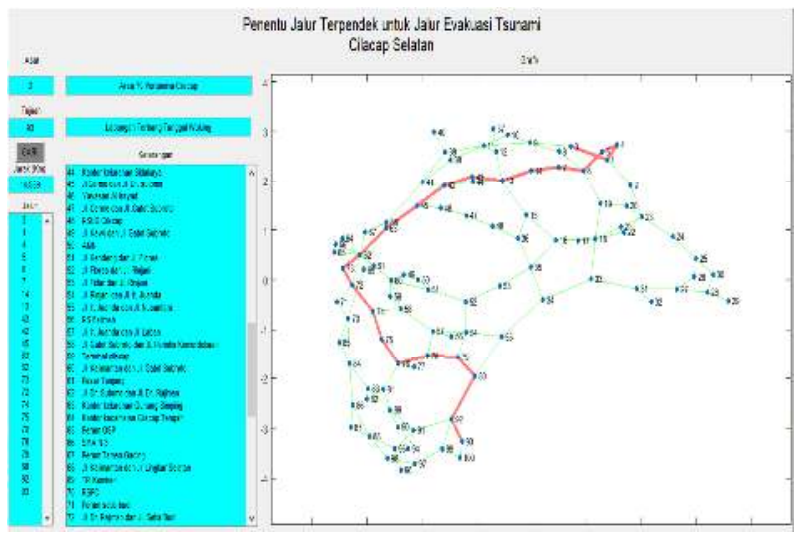

Gambar 11 Tampilan Simulasi pada MATLAB

Perangkat lunak MATLAB berhasil menjalankan simulasi jalur terpendek yang terpilih beserta jarak, rute dan gambar grafiknya. Gambar grafik tersebut berfungsi sebagai pemetaan 100 titik yang sudah ditentukan dan jalur terpendek yang sudah terbentuk setelah menjalankan simulasi ditandai dengan garis edge yang lebih tebal.

\section{KESIMPULAN}

Dari penelitian tentang "Pemanfaatan MATLAB untuk Penentuan Jalur Terpendek Evakuasi Jalur Tsunami di Wilayah Cilacap
Selatan" dapat diambil kesimpulan bahwa dengam memanfaatkan perangkat lunak MATLAB dapat mensimulasikan jalur terpendek evakuasi tsunami di wilayah Cilacap Selatan yang terpilih beserta jarak dan gambar grafiknya.

\section{UCAPAN TERIMAKASIH}

Pelaksanaan penelitian dan penyusunan jurnal ini mendapat bantuan dari berbagai pihak. Oleh karena itu penulis mengucapkan terimakasih kepada Direktorat Riset dan Pengabdian Masyarakat (DRPM) Kemenristek Dikti yang telah membiayai penelitian ini, BPBD Kabupaten Cilacap yang telah membantu memberikan informasi dan data serta rekan-rekan dosen dan mahasiswa PNC yang turut serta membantu pelaksanaan penelitian ini.

\section{DAFTAR PUSTAKA}

[1] Mück, M., (2008). Tsunami Evacuation Modelling. Development and application of a spatial information system supporting tsunami evacuation planning in South-West Bali. Universität Regensburg.

[2] Kurniawan, L, dkk. (2011). Indeks Rawan Bencana Indonesia. Direktorat Pengurangan Risiko Bencana, Deputi Bidang Pencegahan dan kesiapsiagaan, BNPB. Jakarta.

[3] Rachman, A.P. and Suryo, M.S., (2015). Penerapan Sistem Evakuasi Tsunami Di Kawasan Perkotaan Kabupaten Cilacap, Kasus: Kecamatan Cilacap Selatan. Jurnal Permukiman, 10(1), pp.37-48.

[4] Listyaningrum, R., Pratiwi, AF., Riyanto, SD., (2019). Penentuan Jalur Terpendek Evakuasi Bencana Tsunami Di Kecamatan Cilacap Selatan dan Sekitarnya Menggunakan Algoritma Djikstra. Sentrinov Vol.5. pp.2111-2118. Polman Babel.

[5] Munir, R., (2016). Matematika Diskrit. Penerbit Informatika. Bandung

[6] Verdianto, E. (2013). Perancangan Sistem Penentuan Rute Terpendek Jalur Evakuasi 
Jurnal ECOTIPE, Volume 7, No. 1, April 2020, Hal. 47-54

p-ISSN 2355-5068, e-ISSN 2622-4852

Akreditasi Kemenristekdikti (SINTA 4), SK. No.10/E/KPT/2019

DOI: 10.33019/ecotipe.v7i1.1467

Tsunami dengan Algoritma Ant Colony (Studi Kasus: Belawan). Program Studi S1 Ilmu Komputer. Fakultas Ilmu Komputer dan Teknologi Informasi Universitas Sumatera Utara. Medan.

[7] Susani, IM., (2012). Perbandingan Algoritma Djikstra, Bellman-Ford, dan Floyd-Warshall Untuk Mencapai Rute Terpendek. Program Studi Matematika. Fakultas Sains dan Teknologi Universitas Islam Negeri Sunan Kalijaga. Yogyakarta.

[8] Mudhana, IMP., Purnomo, MH dan Nugroho, SMS. (2014) Simulasi Pergerakan Evakuasi Bencana Tsunami Menggunakan Algoritma Boids dan Pathfinding. Seminar Nasional ke - 9: Rekayasa Teknologi Industri dan Informasi.

[9] Zulfa, AM., (2015). Aplikasi Penentuan Rute Evakuasi Bencana Tsunami Kota Padang Menggunakan Algoritma A-Star Berbasis Hybrid Application. Jurusan Ilmu Komputer/Informatika. Fakultas Sains dan Matematika Universitas Diponegoro.

[10] Htun, YY., (2019) Case Study of Shortest Path Algorithms and Implementation using MATLAB. International Journal of Biology, Physic \& Mathematics Vol.4, pp 53-59 